\title{
KEPADATAN DAN KONDISI HABITAT KERANG KIMA (CARDIIDAE: TRIDACNINAE) DI BEBERAPA LOKASI DI PERAIRAN SULAWESI UTARA
}

\author{
Ucu Yanu Arbi \\ Peneliti pada UPT Loka Konservasi Biota Laut, Lembaga IImu Pengetahuan Indonesia-Bitung, Sulawesi Utara \\ Teregistrasi I tanggal: 11 Maret 2010; Diterima setelah perbaikan tanggal: 20 Juli 2010; \\ Disetujui terbit tanggal: 30 Juli 2010
}

\begin{abstract}
ABSTRAK
Kima merupakan salah satu jenis kerang laut yang telah dieksploitasi oleh nelayan Sulawesi Utara dalam skala besar karena memiliki nilai ekonomis yang tinggi. Penelitian ini bertujuan untuk mengetahui kepadatan dan kondisi habitat kerang kima di perairan Sulawesi Utara pada tahun 2007-2009. Daerah penelitian ini meliputi perairan Bitung, Pulau Lembeh, Taman Nasional Bunaken, Likupang, Pulau Talise, Kepulauan Sangihe, dan Kepulauan Talaud. Pengambilan data dilakukan dengan metode rapid reef resources inventory dan metode kuadrat transek garis. Ditemukan 1.064 individu kima yang terdiri atas tujuh jenis, yaitu Tridacna crocea, Tridacna squamosa, Tridacna maxima, Tridacna derasa, Tridacna gigas, Hippopus hippopus, dan Hippopus porcelanus. Kepadatan kima secara keseluruhan di lokasi penelitian rata-rata $0,53 \mathrm{ind} . / \mathrm{m}^{2}$. Kepadatan tertinggi adalah jenis Tridacna crocea (rata-rata $0,32 \mathrm{ind} . / \mathrm{m}^{2}$ ), sedangkan terendah adalah jenis Tridacna gigas, Tridacna derasa, dan Hippopus porcelanus $\left(0,01\right.$ ind. $\left./ \mathrm{m}^{2}\right)$.
\end{abstract}

KATAKUNCI: $\quad$ kepadatan, habitat, kima, perairan Sulawesi Utara

ABSTRACT: Density and habitat of giant clams (Cardiidae: Tridacninae) at some locations in North Sulawesi Waters. By: Ucu Yanu Arbi

\begin{abstract}
Giant clam is one of the sea shells that have been exploited by the fisherman of North Sulawesi, a large scale because it has a high economic value. This study aims to determine the distribution and density of giant clams in North Sulawesi waters in 2007-2009. Research conducted in the waters of Bitung, Pulau Lembeh, Bunaken National Park, Likupang, Talise Island, Sangihe Islands, and Talaud Islands. Data retrieval is done by the rapid reef resources inventory method and the quadrat line transect method. 1.064 individual of giant clams was found consisting of seven species, there are Tridacna crocea, Tridacna squamosa, Tridacna maxima, Tridacna derasa, Tridacna gigas, Hippopus hippopus and Hippopus porcelanus. Density of giant clams density is $0,53 \mathrm{ind} . / \mathrm{m}^{2}$. The highest density of individuals is Tridacna crocea (0,32 ind./m2), while the lowest is Tridacna gigas, Tridacna derasa and Hippopus porcelanus $\left(0.01 \mathrm{ind} . / \mathrm{m}^{2}\right)$.
\end{abstract}

KEYWORDS: $\quad$ density, habitat, giant clams, North Sulawesi waters

\section{PENDAHULUAN}

Kima termasuk jenis kerang laut dari famili Cardiidae kelas Pelecypoda, merupakan jenis kerang dengan ukuran terbesar di dunia dan mampu bertahan hidup sampai umur delapan tahun. Anggota dari famili ini terdiri atas dua genera, yaitu Tridacna dan Hippopus (Keys \& Healey, 2000). Kerang jenis ini hidup menetap dengan cara berasosiasi pada substrat di perairan Indo-Pasifik daerah tropis dan subtropis sampai kedalaman sekitar $20 \mathrm{~m}$. Hampir seluruh jenis dari genus Tridacna memiliki perilaku hidup menempel atau membenamkan cangkang pada substrat keras dengan menggunakan byssus, sedangkan anggota genus Hippopus tidak memiliki byssus dan membenamkan cangkang pada substrat pasir (Knop, 1996). Biota laut ini cukup rentan terhadap perubahan lingkungan dan memilih habitat dengan kondisi air yang jernih. Distribusi geografisnya terbentang dari perairan Pasifik bagian tenggara menuju ke Afrika bagian timur dan meluas ke utara masuk ke wilayah Laut Merah (Braley, 1993).

Kerang kima yang dapat ditemukan cukup mudah di perairan Indonesia (terutama di perairan timur Indonesia) meliputi tujuh jenis kima, antara lain Tridacna crocea, Tridacna squamosa, Tridacna maxima, Tridacna derasa, Tridacna gigas, Hippopus hippopus 
dan Hippopus porcelanus. Di seluruh dunia, diketahui terdapat delapan jenis. Satu jenis yang tidak ditemukan di perairan Indonesia adalah jenis Tridacna tevoroa yang memiliki sebaran di perairan Fiji dan Tonga, wilayah Central Pasifik bagian barat.

Kima merupakan salah satu komoditas perdagangan internasional bernilai ekonomis tinggi sebagai bahan makanan, bangunan, dan kerajinan tangan. Bahkan anakan kima hidup juga menjadi salah satu komoditas dalam perdagangan akuarium hias air laut (Kinch, 2002; Wabnitz et al., 2003). Tingginya nilai jual dan permintaan pasar dari seluruh penjuru dunia mengakibatkan terjadinya eksploitasi yang cenderung berlebihan (over exploitation). Kemungkinan besar Tridacna gigas telah mengalami kepunahan di sebagian besar wilayah perairan Indonesia, terutama di perairan Indonesia bagian barat (Usher, 1994). Kerang kima telah dimasukan ke dalam daftar CITES apendiks II (Klumpp \& Griffiths, 1994) dan daftar UICN Red List of Threatened Species (IUCN, 2007). Peraturan serupa telah dikeluarkan oleh Pemerintah Indonesia melalui Surat Keputusan Menteri Kehutanan No.12/Kpts-II/1987 dan Peraturan Pemerintah No.7/1999 yang mengatakan bahwa kima termasuk biota yang dilindungi (Eliata et al., 2003).

Nelayan Sulawesi Utara telah memanfaatkan moluska sejak zaman dahulu sebagai bahan makanan
(Kinnaird, 2002). Pada umumnya eksploitasi moluska dilakukan dengan berbagai cara, dari yang paling konvensional sampai penggunaan perlengkapan modern (Gabbi, 2000). Penelitian tentang populasi kerang kima perlu dilakukan mengingat terbatasnya data dan informasi kerang kima di wilayah perairan Sulawesi Utara. Penelitian tentang kepadatan kerang kima khusus di wilayah Bunaken dan Selat Lembeh pernah dilakukan, tapi cakupan dalam penelitian tersebut sangat terbatas (Burghardt et al., 2006; Yusuf, 2007).

Tujuan dari penelitian ini adalah untuk memperoleh data dan informasi mengenai sebaran dan kepadatan kima di beberapa lokasi di perairan Sulawesi Utara. Hasil penelitian diharapkan dapat menjadi bahan acuan dalam pengambilan kebijakan pengelolaan wilayah pesisir dan pemanfaatan sumber daya alam berkelanjutan oleh pihak-pihak yang berkepentingan.

\section{BAHAN DAN METODE}

Penelitian ini dilakukan di beberapa lokasi di perairan Sulawesi Utara pada tahun 2007-2009. Daerah penelitian dibagi menjadi tujuh lokasi dengan jumlah stasiun pada masing-masing lokasi tidak sama, tergantung pada luasan terumbu karang di lokasi tersebut (Gambar 1).

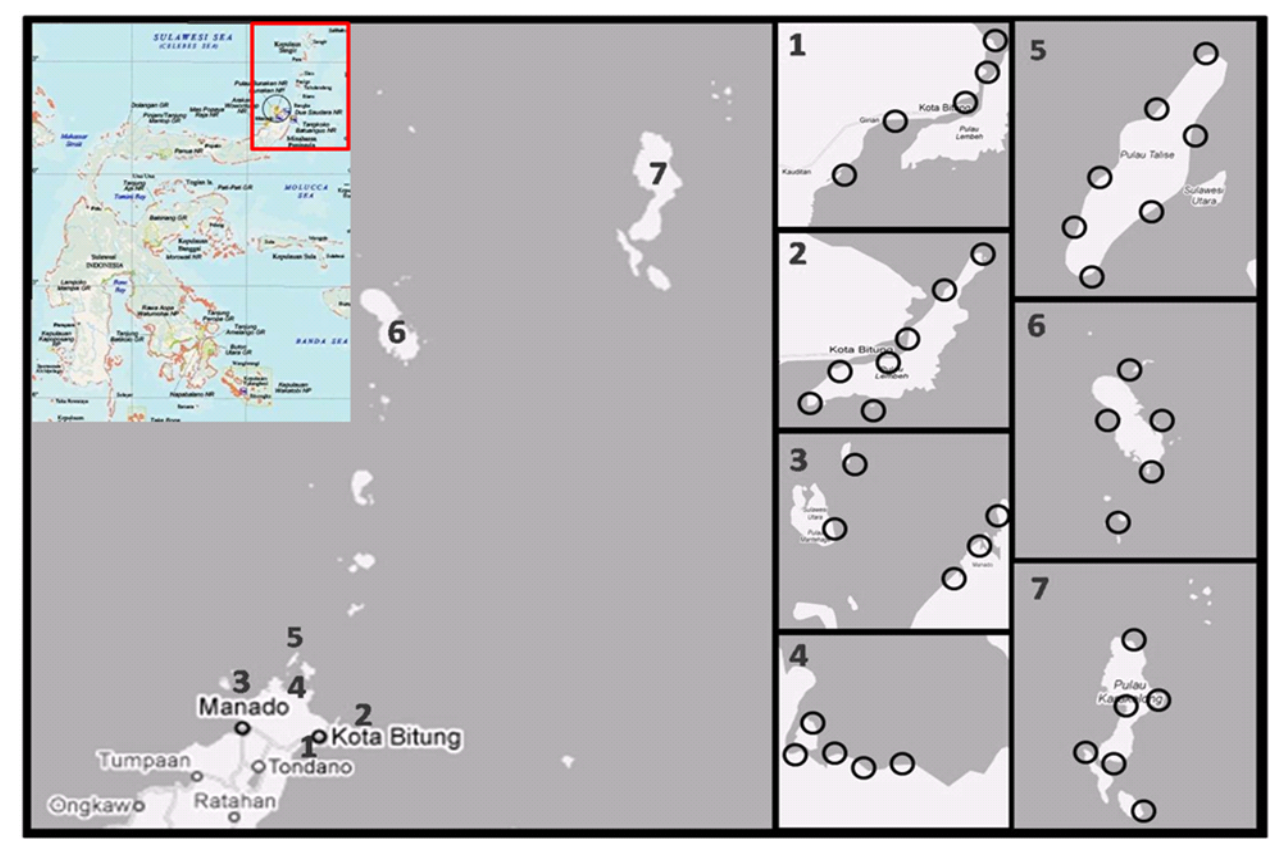

Gambar 1. Peta lokasi penelitian pada tujuh lokasi di perairan Sulawesi Utara.

Figure 1. Map of observation on seven locations in North Sulawesi waters.

Keterangan/Remarks:1. Bitung; 2. Pulau Lembeh; 3. Taman Nasional Bunaken; 4. Likupang; 5. Pulau Talise; 6. Kepulauan Sangihe; 7. Kepulauan Talaud. Tanda lingkaran menunjukan lokasi dilakukan observasi terhadap kima 
Lokasi pertama di pesisir Bitung dilakukan bulan Maret, Juli, dan Agustus 2008 serta April 2009. Lokasi kedua di Pulau Lembeh dilakukan bulan Mei 2007, April, Mei, Juni, dan Agustus 2008, serta Oktober 2009. Lokasi ketiga di Taman Nasional Bunaken dilakukan bulan April, Juni, dan Agustus 2008. Lokasi keempat di Likupang dilakukan bulan April dan Mei 2009. Lokasi kelima di Kepulauan Sangihe dilakukan bulan Mei 2009. Lokasi keenam di Kepulauan Talaud dilakukan bulan Mei 2009. Lokasi ketujuh di Pulau Talise dilakukan bulan Juli, Agustus, dan Oktober 2009.

Metode yang digunakan adalah rapid reef resources inventory dan pengambilan contoh dilakukan bantuan perlengkapan selam SCUBA dan snorkeling. Pencacahan dilakukan sepanjang $10 \mathrm{~m}$ dengan lebar 2,5 $\mathrm{m}$ ke arah kanan dan kiri dari garis transek. Luas pengamatan setiap titik adalah $50 \mathrm{~m}^{2}$ (10X5 m). Semua jenis kima yang ditemukan dicatat jumlahnya berdasarkan atas jenis. Identifikasi jenis kima merujuk pada beberapa literatur yang terkait (Copland \& Lucas, 1988; Knop, 1996; Lamprell \& Whitehead, 1992).

Penghitungan kepadatan kima menggunakan formula sebagai berikut (Snedecor \& Cochran, 1980):

$\mathrm{K}=\mathrm{Di} /(\operatorname{nixA})$ $(1$

di mana:

$\mathrm{K}=$ rata-rata kepadatan (ind. $/ \mathrm{m}^{2}$ )

$\mathrm{ni}=$ jumlah daerah pengamatan

Di =jumlah individu di seluruh daerah pengamatan

$A=$ luas masing-masing daerah

Komposisi jenis dihitung berdasarkan atas jumlah individu masing-masing jenis dibagi dengan total individu dalam satu stasiun. Selain mencatat jumlah jenis kima, kondisi habitat yang ditemukannya juga dicatat. Penilaian kondisi habitat berdasarkan atas kode bentik (benthic code) yang mengacu pada English et al. (1994). Kode yang digunakan adalah sebagai berikut $C C$ (coral covered) untuk substrat berupa tutupan karang hidup, DCA (dead coral algae) untuk substrat berupa batu karang yang mati, FAV (Faviidae) untuk substrat dari famili Faviidae, $P O R$ (Porites) untuk substrat dari genus Porites, $R B$ (Rubble) untuk substrat patahan-patahan karang mati, dan $S$ (Sand) untuk substrat berupa pasir.

\section{HASIL DAN BAHASAN}

\section{Kondisi Umum Lokasi Penelitian}

Perairan Sulawesi Utara memiliki cukup banyak pulau-pulau kecil yang tersebar mulai dari semenanjung utara Pulau Sulawesi sampai ke bagian selatan negara tetangga Filipina. Secara umum, kondisi perairan di Sulawesi Utara sangat jernih dengan garis pantai yang dikelilingi oleh rata-rata terumbu yang bahkan membentuk gugusan pulau pada beberapa lokasi. Sebagian lokasi lain memiliki tipe pantai yang miring, bahkan tidak jarang berupa tebing dengan kemiringan penuh. Ekosistem tersebut membentuk rantai makanan yang sangat kompleks yang disusun oleh biota laut yang beranekaragam jenis dan jumlahnya. Pola arus yang memungkinkan pertukaran massa air yang melewati wilayah ini memungkinkan tumbuh suburnya ekosistem terumbu karang. Kekayaan jenis biota laut semakin tinggi pada ekosistem terumbu karang sebagai akibat pola pertukaran massa air dan kandungan oksigen serta tercukupinya pasokan sinar matahari (Taylor, 1971).

Tipe ekosistem terumbu karang di perairan Sulawesi Utara cukup bervariasi, dari yang memiliki rata-rata terumbu yang luas sampai yang sempit, dari yang landai sampai tebing, dengan keunikan masingmasing. Sejumlah pulau di kawasan ini tidak berpenghuni, terutama pulau-pulau kecil. Sebagian terumbu karang tumbuh berdampingan dengan padang lamun dan sebagian lain tidak ditemukan pertumbuhan lamun. Daerah-daerah yang telah mendapatkan status perlindungan, seperti Wori, Pulau Mantehage, dan Pulau Nain yang termasuk daerah penyangga Taman Nasional Bunaken memiliki terumbu karang yang cukup baik. Hal ini juga terjadi pada pulau-pulau kecil yang jauh dari dari pemukiman penduduk. Akan tetapi tidak sedikit wilayah yang kawasan terumbu karangnya telah mengalami degradasi karena pemanfaatan sumber daya laut yang tidak ramah lingkungan, misalnya pengeboman dan penggunaan potassium yang marak terjadi di masa lalu.

\section{Sebaran dan Komposisi Jenis Kima}

Hasil penelitian ini dapat mengumpulkan 1.064 individu dari tujuh jenis kima yang terdiri atas 638 individu Tridacna crocea, 199 individu Tridacna maxima, 92 individu Tridacna squamosa, delapan individu Tridcana gigas, tiga individu Tridacna derasa, 106 individu Hippopus hippopus, dan 18 individu Hippopus porcelanus (Tabel 1). Banyaknya jumlah individu yang ditemukan kemungkinan besar karena peraran tiga faktor penting, yaitu kondisi habitat, sumber makanan maupun keberadaan pemangsa. 
Tabel 1. Jumlah jenis dan sebaran kima pada masing-masing lokasi penelitian Table 1. Number of species and distribution of giant clams on each locations

\begin{tabular}{|c|c|c|c|c|c|c|c|c|c|c|}
\hline \multirow[b]{2}{*}{ No. } & \multirow[b]{2}{*}{$\begin{array}{l}\text { Lokasi/ } \\
\text { Location }\end{array}$} & \multirow[b]{2}{*}{$\begin{array}{c}\text { Stasiun/ } \\
\text { Station }\end{array}$} & \multicolumn{7}{|c|}{ Jumlah tiap jenis/The number of each type } & \multirow[b]{2}{*}{$\begin{array}{c}\text { Jumlah/ } \\
\text { Total }\end{array}$} \\
\hline & & & $\begin{array}{c}\text { Tridacna } \\
\text { crocea }\end{array}$ & $\begin{array}{l}\text { Tridacna } \\
\text { maxima }\end{array}$ & $\begin{array}{c}\text { Tridacna } \\
\text { squamosa }\end{array}$ & $\begin{array}{c}\text { Tridacna } \\
\text { gigas }\end{array}$ & $\begin{array}{c}\text { Tridacna } \\
\text { derasa }\end{array}$ & $\begin{array}{l}\text { Hippopus } \\
\text { hippopus }\end{array}$ & $\begin{array}{l}\text { Hippopus } \\
\text { porcelanus }\end{array}$ & \\
\hline \multirow[t]{5}{*}{1.} & Bitung & 1 & 24 & 4 & 1 & 1 & & 6 & 1 & 37 \\
\hline & & 2 & 19 & 3 & 3 & & & 3 & & 28 \\
\hline & & 3 & 11 & 3 & 1 & & & 1 & & 16 \\
\hline & & 4 & 8 & 1 & 2 & 1 & & 2 & 1 & 15 \\
\hline & & 5 & 13 & 4 & 2 & & 1 & & & 20 \\
\hline \multirow[t]{7}{*}{2.} & Lembeh & 1 & 14 & 2 & & & & 1 & & 17 \\
\hline & & 2 & 18 & 4 & 1 & & & & & 23 \\
\hline & & 3 & 7 & 1 & 1 & & & 1 & & 10 \\
\hline & & 4 & 5 & 1 & & & & & & 6 \\
\hline & & 5 & 11 & 3 & 3 & & & 1 & & 18 \\
\hline & & 6 & 9 & 1 & 1 & & & & & 11 \\
\hline & & 7 & 23 & 6 & 3 & 1 & & & & 33 \\
\hline \multirow[t]{5}{*}{3.} & Bunaken & 1 & 10 & 5 & 4 & & & & & 19 \\
\hline & & 2 & 5 & & 1 & & & & & 6 \\
\hline & & 3 & 34 & 8 & 5 & & & 3 & 1 & 51 \\
\hline & & 4 & 57 & 12 & 9 & 2 & 1 & 8 & 3 & 92 \\
\hline & & 5 & 16 & 2 & 2 & 1 & & & & 21 \\
\hline \multirow[t]{5}{*}{4.} & Likupang & 1 & 2 & & & & & & & 2 \\
\hline & & 2 & 12 & 6 & 1 & & & & & 19 \\
\hline & & 3 & 49 & 21 & 13 & 1 & & & & 84 \\
\hline & & 4 & 44 & 15 & 6 & & & & & 65 \\
\hline & & 5 & 16 & 9 & 2 & & & & & 27 \\
\hline \multirow[t]{7}{*}{5.} & Talise & 1 & 15 & 7 & 2 & & & 12 & 2 & 38 \\
\hline & & 2 & 7 & 2 & 2 & & & 4 & & 15 \\
\hline & & 3 & 36 & 13 & 5 & & & 11 & & 65 \\
\hline & & 4 & 22 & 10 & 1 & & & 7 & 1 & 41 \\
\hline & & 5 & 14 & 7 & 1 & 1 & 1 & 9 & 2 & 35 \\
\hline & & 6 & 20 & 9 & 3 & & & 6 & & 38 \\
\hline & & 7 & 17 & 3 & & & & 15 & 1 & 36 \\
\hline \multirow[t]{5}{*}{6.} & Sangihe & 1 & 4 & 2 & 2 & & & & 1 & 9 \\
\hline & & 2 & 11 & 7 & 1 & & & & & 19 \\
\hline & & 3 & 3 & 1 & & & & 1 & & 5 \\
\hline & & 4 & 2 & 3 & & & & 3 & 2 & 10 \\
\hline & & 5 & 8 & 1 & 1 & & & 1 & & 11 \\
\hline \multirow[t]{8}{*}{7.} & Talaud & 1 & 8 & 3 & 1 & & & & & 12 \\
\hline & & 2 & 15 & 8 & 3 & & & 1 & 1 & 28 \\
\hline & & 3 & 14 & 4 & 1 & & & 6 & 1 & 26 \\
\hline & & 4 & 17 & 3 & 6 & & & 1 & & 27 \\
\hline & & 5 & 8 & 1 & 2 & & & 3 & & 14 \\
\hline & & 6 & 10 & 4 & & & & & 1 & 15 \\
\hline & Jumlah & & 638 & 199 & 92 & 8 & 3 & 106 & 18 & 1.064 \\
\hline & $\begin{array}{l}\text { Persentase } \\
\text { (\%) }\end{array}$ & & 59,96 & 18,70 & 8,65 & 0,75 & 0,28 & 9,96 & 1,69 & \\
\hline
\end{tabular}

Jika dibandingkan dengan penelitian di daerah lain, hasil yang didapat dalam penelitian ini termasuk tinggi. Selain karena faktor kondisi habitat, waktu penelitian yang lebih lama dan cakupan daerah penelitian yang lebih luas diduga juga mempengaruhi hasil penelitian ini. Beberapa hasil penelitian tentang kima yang pernah dilakukan di beberapa lokasi disajikan dalam Tabel 2. 
Tabel 2. Jumlah jenis kima berdasarkan atas hasil penelitian di berbagai lokasi di Indonesia Table 2. The number of species of giant clams based on research results at various locations in Indonesia

\begin{tabular}{|c|c|c|c|}
\hline No. & Lokasi penelitian/Location research & $\begin{array}{c}\text { Jumlah jenis } \\
\text { yang ditemukan/ } \\
\text { The number of } \\
\text { species found }\end{array}$ & Sumber/Source \\
\hline 1. & Pulau Pari, DKI Jakarta & 4 jenis & Panggabean (1985) \\
\hline 2. & Kepulauan Aru, Maluku & 3 jenis & Taufik (1987) \\
\hline 3. & Kepulauan Banda dan Lucipara, Maluku & 6 jenis & Arifin et al. (1993) \\
\hline 4. & Kepulauan Togean dan Banggai & 6 jenis & Allen \& McKenna (2001) \\
\hline 5. & Raja Ampat, Papua Barat & 7 jenis & McKenna et al. (2002) \\
\hline 6. & Taman Nasional Wakatobi, Sulawesi Tenggara & 2 jenis & Pet-Soede \& Erdmann (2003) \\
\hline 7. & Kepulauan Natuna dan Anambas & 1 jenis & Tan \& Kastoro (2004) \\
\hline 8. & Pulau Morotai, Maluku Utara & 3 jenis & Cappenberg (2005) \\
\hline 9. & Taman Nasional Bunaken, Sulawesi Utara & 3 jenis & Burghardt et al. (2006) \\
\hline 10. & Kepulauan Derawan, Kalimantan Timur & 4 jenis & Cappenberg (2007) \\
\hline 11. & Teluk Ambon, Maluku & 4 jenis & Poorten (2007) \\
\hline 12. & Krakatau, Banten & 4 jenis & Yusuf (2007) \\
\hline 13. & Taman Nasional Kepulauan Seribu, DKI Jakarta & 3 jenis & Yusuf (2007) \\
\hline 14. & Selat Lembeh, Sulawesi Utara & 4 jenis & Yusuf (2007) \\
\hline 15. & $\begin{array}{l}\text { Kepulauan Banyak dan Simeulue, Nangroe } \\
\text { Aceh Daraussalam }\end{array}$ & 4 jenis & Herdiana et al. (2008) \\
\hline 16. & Kei Kecil, Maluku & 6 jenis & Hernawan (2009) \\
\hline
\end{tabular}

Dilihat dari lokasi penelitian, maka jumlah pada masing-masing lokasi di perairan Sulawesi Utara sebagai berikut perairan Pulau Talise 268 individu, perairan Likupang 197 individu, perairan sekitar Bunaken 189 individu, perairan Kepulauan Talaud 122 individu, perairan Pulau Lembeh 118 individu, perairan Bitung 116 individu, dan perairan Kepulauan Sangihe 54 individu. Dari hasil tersebut dapat dikatakan bahwa penyebaran kima pada setiap lokasi tidak sama, baik dalam hal jumlah jenis maupun jumlah individu yang ditemukan. Penyebab dari perbedaan jumlah tersebut kemungkinan selain karena faktor kondisi lingkungan juga karena kegiatan eksploitasi oleh nelayan terhadap jenis-jenis kima. Perubahan lingkungan, baik secara alamiah maupun karena pengaruh aktivitas manusia merupakan hambatan terbesar bagi populasi kima.

Dari tujuh lokasi penelitian ditemukan total 1.064 individu untuk keseluruhan jenis kima. Jenis Tridacna crocea ditemukan di seluruh stasiun sehingga dapat dikatakan sebagai jenis yang dominan (59,96\% dari seluruh kima yang ditemukan). Jenis Tridacna maxima dan Tridacna squamosa hampir ditemukan di seluruh stasiun dengan persentase masing-masing 18,7 dan 8,65\%. Jenis Hippopus hippopus ditemukan di sebagian dari seluruh stasiun dengan persentase $9,96 \%$. Jenis-jenis yang ditemukan hanya pada beberapa stasiun adalah Tridacna gigas, Tridacna derasa, dan Hippopus porcelanus dengan persentase masing-masing 0,$75 ; 0,28$; dan $1,69 \%$.

\section{Kepadatan Menurut Jenis Kima}

Hasil perhitungan menunjukan bahwa Tridacna crocea adalah jenis yang memiliki kepadatan paling tinggi, yaitu 0,32 ind. $/ \mathrm{m}^{2}$, sedangkan kepadatan terendah adalah jenis Tridacna gigas dan Tridacna derasa yaitu masing-masing $0,01 \mathrm{ind} . / \mathrm{m}^{2}$. Ditinjau menurut lokasinya, perairan Bunaken, Likupang, dan Talise merupakan lokasi yang memiliki kepadatan tertinggi $\left(0,11\right.$ ind. $\left./ \mathrm{m}^{2}\right)$ dan Kepulauan Sangihe memiliki kepadatan terendah $\left(0,03\right.$ ind.$\left./ \mathrm{m}^{2}\right)$. Kepadatan kima menurut lokasi penelitian disajikan dalam Tabel 3. 
Tabel 3. Kepadatan kima (ind. $/ \mathrm{m}^{2}$ ) pada masing-masing lokasi penelitian

Table 3. Density of giant clams (ind. $\left./ \mathrm{m}^{2}\right)$ on each locations

\begin{tabular}{|c|c|c|c|c|c|c|c|c|c|}
\hline \multirow[b]{2}{*}{ No. } & \multirow{2}{*}{$\begin{array}{l}\text { Lokasi/ } \\
\text { Location }\end{array}$} & \multicolumn{7}{|c|}{ Kepadatan/Density (Ind./m²) } & \multirow{2}{*}{$\begin{array}{l}\text { Rata-rata } \\
\text { Average }\end{array}$} \\
\hline & & $\begin{array}{c}\text { Tridacna } \\
\text { crocea }\end{array}$ & $\begin{array}{c}\text { Tridacna } \\
\text { maxima }\end{array}$ & $\begin{array}{c}\text { Tridacna } \\
\text { squamosa }\end{array}$ & $\begin{array}{c}\text { Tridacna } \\
\text { gigas }\end{array}$ & $\begin{array}{c}\text { Tridacna } \\
\text { derasa }\end{array}$ & $\begin{array}{l}\text { Hippopus } \\
\text { hippopus }\end{array}$ & $\begin{array}{c}\text { Hippopus } \\
\text { porcelanus }\end{array}$ & \\
\hline 1. & Bitung & 0,30 & 0,06 & 0,04 & 0,01 & 0,01 & 0,05 & 0,01 & 0,07 \\
\hline 2. & Lembeh & 0,25 & 0,05 & 0,03 & 0,01 & 0 & 0,01 & 0 & 0,05 \\
\hline 3. & Bunaken & 0,49 & 0,11 & 0,08 & 0,01 & 0,01 & 0,04 & 0,02 & 0,11 \\
\hline 4. & Likupang & 0,49 & 0,20 & 0,09 & 0,01 & 0 & 0 & 0 & 0,11 \\
\hline 5. & Talise & 0,37 & 0,15 & 0,04 & 0,01 & 0,01 & 0,18 & 0,02 & 0,11 \\
\hline 6. & Sangihe & 0,11 & 0,06 & 0,02 & 0 & 0 & 0,02 & 0,01 & 0,03 \\
\hline \multirow[t]{2}{*}{7.} & Talaud & 0,24 & 0,08 & 0,04 & 0 & 0 & 0,04 & 0,01 & 0,06 \\
\hline & Rata-rata & 0,32 & 0,1 & 0,05 & 0,01 & 0,01 & 0,05 & 0,01 & 0,53 \\
\hline
\end{tabular}

Secara keseluruhan, kepadatan individu kima dalam penelitian ini adalah 0,53 ind. $/ \mathrm{m}^{2}$, yang berarti bahwa dalam daerah seluas satu hektar terdapat 5.300 individu kima. Berdasarkan atas kriteria kepadatan kima, jika nilai kepadatan antara kurang dari satu, maka populasi dalam kondisi rendah (Planes et al., 1993). Jika dibandingkan dengan penelitian di daerah lain, angka tersebut terbilang tinggi. Braley (1993) pada penelitian di Kepulauan Kei dan Tanimbar mengatakan kepadatan kima 0,002 ind. $/ \mathrm{m}^{2}$ (20 ind./ ha). Yusuf (2007) mengatakan kepadatan kima di Krakatau, Banten 0,017 ind./m² (170 ind./ha), di Kepulauan Seribu, DKI Jakarta 0,03 ind. $/ \mathrm{m}^{2}$ (300 ind./ ha), serta di sekitar Manado dan Bitung, Sulawesi Utara $0,03 \mathrm{ind} . / \mathrm{m}^{2}$ (300 ind./ha). Perbedaan nilai yang didapat kemungkinan besar karena waktu penelitian yang lebih lama dengan cakupan daerah yang lebih luas dan bervariasi.

Fenomena kepadatan Tridacna crocea tertinggi serupa dengan hasil penelitian Chantrapornsyl et al. (1996) di Pulau Lee-Pae, Laut Andaman, serta hasil penelitian Upanoi \& Banchungmanee (2000) di Pulau Adang, Bitsi, Hin-ngam, Lipe dan Talang, Laut Andaman. Hasil penelitian Eliata et al. (2003) di Pulau Pari, DKI Jakarta juga menemukan fenomena yang sama. Jenis ini memiliki ukuran paling kecil di antara jenis kima dan hidup membenamkan cangkang ke dalam batu karang. Hal ini menyebabkan kima jenis ini paling sedikit mendapatkan tekanan eksploitasi dari manusia maupun gangguan dari pemangsa, sehingga populasinya relatif paling tinggi dibandingkan dengan jenis-jenis kima lainnya.

\section{Habitat Kima}

Kima memiliki habitat pada terumbu karang dengan cara menempelkan atau menenggelamkan cangkang pada substrat dengan menggunakan byssus. Zat kimia yang dihasilkan byssus menjadikan substrat berubah lunak, dan memudahkan penetrasi byssus pada substrat yang keras. Kadang seluruh bagian cangkang kima tenggelam pada batu karang menyulitkan pengambilan dan identifikasi, sehingga kemungkinan untuk dapat mengambilnya adalah dengan cara merusak batu karang tersebut. Jenis Hippopus memiliki habitat pada pasir, terutama pasir putih dengan cara membenamkan sebagian atau seluruh bagian cangkangnya. Cukup banyak lokasi di Sulawesi Utara dengan substrat berupa pasir putih, sehingga memungkinkan jenis ini dapat ditemukan. Kondisi fisik dan kimia perairan yang baik memungkinkan terumbu karang dan biota laut yang berasosiasi di dalamnya tumbuh dengan baik, termasuk moluska secara umum, khususnya jenisjenis kima.

Pola arus yang cukup memadai yang melalui wilayah Sulawesi Utara memungkinkan pergantian massa air. Sulawesi Utara merupakan salah satu pintu keluar dan masuknya pergerakan massa air yang berasal dari Samudera Pasifik ke Samudera Hindia, dan sebaliknya dengan siklus yang cukup teratur. Pergantian massa air tersebut membawa bahan makanan yang cukup melimpah, terutama dari proses pengadukan endapan dari perairan dalam. Sirkulasi air yang teratur juga memungkinkan tercukupinya kandungan oksigen dalam air untuk mendukung kehidupan kima.

Keberadaan pemangsa juga merupakan faktor penting bagi kelangsungan hidup kima, dan semua organisme. Walaupun habitat memungkinkan untuk hidup, dan sumber makanan tersedia dalam jumlah melimpah, tetapi jika pemangsa juga dalam kondisi melimpah, maka populasi suatu jenis biota laut tidak akan melimpah. Pemangsa bagi kima yang paling besar bahkan tidak hanya berupa biota laut lainnya, tetapi manusia. Tingginya nilai jual menjadikan biota ini dijadikan sebagai sasaran perikanan yang cukup menggiurkan. Kegiatan pengambilan kima di alam sudah dilakukan oleh masyarakat nelayan tradisional 
sejak zaman dahulu, baik untuk kebutuhan protein sehari-hari, juga sebagai komoditas untuk ditukarkan dengan kebutuhan hidup lainnya. Pengambilan kima di alam berlangsung sampai sekarang, dengan perlengkapan yang lebih canggih, sehingga sangat sulit menemukan kima dalam ukuran besar di habitat alami. Kegiatan ini menjadi salah satu ancaman terbesar dari kepunahan kima, selain faktor-faktor lain.
Pengamatan tentang sebaran kima berdasarkan atas habitat atau tipe substrat di perairan Sulawesi Utara ditemukan kima yang hidup pada enam tipe substrat, yaitu $C C$ (tutupan karang hidup), DCA (karang mati beralga), POR (karang genus Porites), $F A V$ (karang famili Faviidae), $R B$ (patahan karang), dan $S$ (hamparan pasir). Perbandingan jenis kima dan persentase pemilihan habitat pada masing-masing lokasi penelitian disajikan pada Gambar 2.

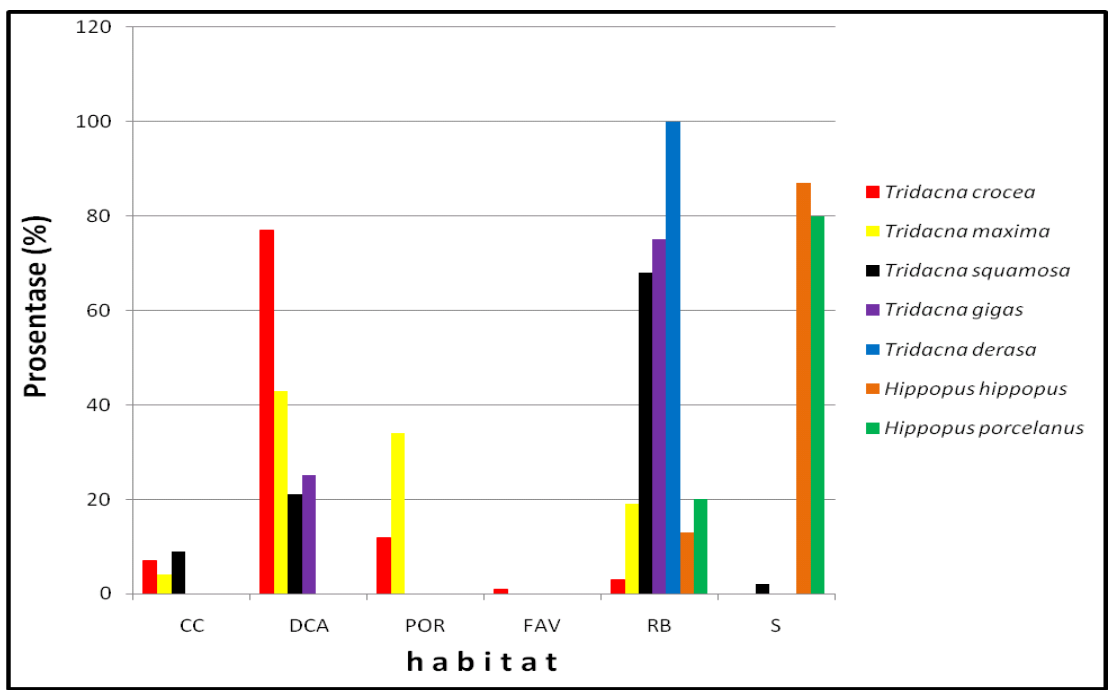

Gambar 2. Jenis kima dan persentase pemilihan habitatnya di perairan Sulawesi Utara.

Figure 2. Giant clams and the percentage of habitat selection in North Sulawesi waters.

Substrat tempat hidup kima Tridacna crocea sebagian besar merupakan bongkahan karang mati yang ditumbuhi alga (77\%), karang genus Porites $(12 \%)$, karang hidup $(7 \%)$, patahan karang $(3 \%)$, dan karang famili Faviidae (1\%). Mudjiono (1988) mengatakan bahwa jenis kima ini hidup membenamkan seluruh cangkangnya pada bongkahan karang. Kima ini mengebor karang dengan dibantu zat kimia untuk melunakan karang. Tridacna maxima ditemukan pada karang mati yang ditumbuhi alga (43\%), karang genus Porites (34\%), patahan karang (19\%), serta karang hidup (4\%). Jenis kima ini membenamkan sebagian cangkangnya pada batu karang (Mudjiono, 1988), sehingga dapat hidup pada patahan karang, selama ada celah untuk memasukan byssus.

Tridacna squamosa ditemukan pada patahan karang (68\%), bongkahan karang mati yang ditumbuhi alga (21\%), karang hidup (9\%), dan hamparan pasir (2\%). Jenis Tridacna gigas ditemukan pada patahan karang $(75 \%)$ dan bongkahan karang mati yang ditumbuhi alga (25\%). Tridacna derasa ditemukan pada patahan karang (100\%). Tiga jenis kima tersebut tidak membenamkan cangkangnya pada batu karang, tapi hanya melekatkan byssus pada substrat. Patahan karang genus Acropora, menjadi habitat utama Tridacna squamosa, Tridacna gigas, dan Tridacna derasa (Knop, 1996; Calumpong, 1992). Hippopus hippopus ditemukan pada hamparan pasir (87\%) serta patahan karang (13\%). Sedangkan Hippopus porcelanus ditemukan pada hamparan pasir (80\%) dan patahan karang (20\%). Hal ini sesuai dengan pendapat Newman \& Gomez (2002). Di Pulau Talise Hippopus hippopus dan Hippopus porcelanus juga ditemukan di padang lamun. Nenek moyang kerang Tridacninae tidak hidup di terumbu karang, justru hidup di padang lamun (Harzhauser et al., 2008). Calumpong (1992) mengatakan bahwa kima dari genus Hippopus juga dapat dibudidayakan di daerah padang lamun dengan syarat kondisi fisik perairan bagus.

Lokasi yang memiliki jumlah individu kima tertinggi adalah di Pulau Talise. Kondisi habitat di lokasi tersebut memiliki tipe substrat yang bervariasi dengan ekosistem yang cukup baik. Dalam satu lokasi pengamatan, terdapat daerah berpasir, bongkahan karang boulder atau karang masif, serta karang bercabang dan patahan-patahan karang. Substrat berupa daerah berpasir cocok sebagai habitat untuk Hippopus (Newman \& Gomez, 2002), sedangkan substrat karang keras cocok untuk Tridacna 
(Mudjiono, 1988; Knop, 1996). Sedangkan lokasi yang memiliki jumlah individu kima terendah adalah Kepulauan Sangihe. Sedikitnya jumlah kima yang ditemukan pada lokasi ini kemungkinan besar disebabkan karena waktu penelitian yang relatif lebih singkat dibanding dengan lokasi lain. pengamatan pada lokasi ini juga tidak menyeluruh seperti halnya lokasi-lokasi lain.

\section{KESIMPULAN DAN SARAN}

\section{Kesimpulan}

1. Ditemukan tujuh jenis kima di perairan Sulawesi Utara, yaitu Tridacna crocea, Tridacna squamosa, Tridacna maxima, Tridacna derasa, Tridacna gigas, Hippopus hippopus dan Hippopus porcelanus.

2. Jenis yang memiliki kepadatan tertinggi adalah Tridacna crocea $\left(0,32\right.$ ind. $\left./ \mathrm{m}^{2}\right)$, dan terendah Tridacna gigas dan Tridacna derasa $\left(0,01 \mathrm{ind} . / \mathrm{m}^{2}\right)$.

3. Tridacna crocea merupakan jenis yang memiliki seraran terluas dan dapat ditemukan di setiap lokasi.

4. Habitat kima di Sulawesi Utara terdapat pada enam tipe substrat dengan patahan karang merupakan tipe substrat yang disukai oleh ketujuh jenis kima.

\section{Saran}

1. Tindakan dan upaya nyata dalam perlindungan kerang kima perlu segera dilakukan oleh pihapihak terkait yang bertanggung jawab untuk melindungi populasi kima di perairan Sulawesi Utara. Pemerintah melalui kebijakan daerah yang mengatur pemanfaatan serta upaya konservasi berbagai jenis kima dengan sistem konservasi total (no take area).

2. Berdasarkan atas hasil penelitian, daerah yang paling cocok untuk konservasi adalah Pulau Nain dan/atau Pulau Talise, dengan mempertimbangkan variasi substrat yang bagus sebagai habitat kima.

3. Pelaksanaan kearifan lokal, semacam sasi di Maluku perlu diterapkan pada lokasi-lokasi yang memungkinkan.

\section{PERSANTUNAN}

Data yang ditampilkan merupakan gabungan dari beberapa kegiatan penelitian tahun 2007-2009. Penelitian tersebut adalah 1) penelitian biodiversitas biota laut di Selat Lembeh, T. A. 2007 dan 2008, UPT Loka Konservasi Biota Laut, Lembaga IImu Pengetahuan Indonesia-Bitung, Sulawesi Utara, 2) penelitian biodiversitas biota laut di perairan Wori dan Sekitarnya, T. A. 2008, UPT Loka Konservasi Biota Laut, Lembaga IImu Pengetahuan Indonesia-Bitung, Sulawesi Utara, 3) penelitian biodiversitas biota laut di perairan Likupang, T. A. 2009, Loka Konservasi Biota Laut, Lembaga IImu Pengetahuan IndonesiaBitung, Sulawesi Utara, 4) ekspedisi widya nusantara Lembaga Ilmu Pengetahuan Indonesia di perairan Sangihe-Talaud, T. A. 2009, Loka Konservasi Biota Laut, Lembaga Ilmu Pengetahuan Indonesia-Bitung, Sulawesi Utara, serta 5) penelitian biodiversitas biota laut di Pulau Talise, T. A. 2009, Insentif Riset Peneliti dan Perekayasa, Loka Konservasi Biota Laut, Lembaga IImu Pengetahuan Indonesia-Bitung, Sulawesi Utara.

\section{DAFTAR PUSTAKA}

Allen, G. R. \& S. A. McKenna (eds.). 2001. A marine rapid assessment of the Togean and Banggai Islands, Sulawesi, Indonesia. RAP Bulletin of Biological Assessment 20. Conservation International. Washington D. C. 145 pp.

Arifin, Z., K. Sumadiharga, \& A. Syahailatua. 1993. Potensi sumber daya perikanan kima (Tridacnidae) di perairan Maluku dan Irian Jaya. Prosiding Simposium Perikanan Indonesia I. Jakarta. Tanggal 25-27 Agutus 1993. 46-53.

Braley, R. D. 1993. Report on the relative assessment of hatchery and oceannursery sites in Southeast Maluku, Eastern Indonesia, for the culture of ggiant clams. Report for Minasanega Persada. James Cook University. Pattimura University. 59 pp.

Burghardt, I., R. Carvalho, D. Eheberg, G. Gerung, F. Kaligis, G. Mamangkey, M. Schrödl, E. Schwabe, V. Vonnemann, \& H. Wägele. 2006. Molluscan Diversity at Bunaken National Park, Sulawesi. Journal Zoolical Society of Wallacea. 2: 29-43. 
Chantrapornsyl, S., K. Kittiwattanawong, \& K. Adulyanukosol. 1996. Distribution and abundance of giant clams around Lee-Pae Island, the Andaman Sea, Thailand. Phuket marine Biological Center Special Publication. 16: 195-200.

Calumpong, H. P. (ed.). 1992. The Giant Clam: An Ocean Culture Manual. ACIAR Monograph 16. Canberra. 68 pp.

Cappenberg, H. A. W. 2005. Makrobenthos di perairan terumbu Pulau Morotai. Laporan Pusat Penelitian Oseanografi-Lembaga IImu Pengetahuan Indonesia. Jakarta. $10 \mathrm{pp}$.

Cappenberg, H. A. W. 2007. Sebaran dan kepadatan kima (Tridacnidae) di perairan Kepulauan Derawan, Kalimantan Timur. Journal of Fisheries Sci. IX (2): 220-225.

Copland, J. W. \& J. S. Lucas (eds.). 1988. Giant Clams in Asia and the Pacific. Australian Centre of International Agricultural Research. Canberra. 274 pp.

Eliata, A., F. Zahida, N. J. Wibowo, \& L. M. G. Panggabean. 2003. Abundance of giant clams in coral reef ecosystem at Pari Island: A population comparison of 2003's to 1984's data. Biota. 8 (3): 149-152.

English, S., C. Wilkinson, \& V. Baker. 1994. Survey Manual for Tropical Marine Resources. AseanAustralia Marine Science. Townsville. 117 pp.

Gabbi, G. 2000. Shells, Guide to the Jewels of the Sea. Periplus. Turin. 168 pp.

Harzhauser, M., M. Gross, \& H. Binder. 2008. Biostratigraphy of middle miocene (sarmatian) wetland system in an Eastern Alpine intramontane basin: The terrestrial gastropods approach. Geologica Carpathica. 59 (1): 45-58.

Herdiana, Y., T. Kartawijaya, R. L. Ardiwijaya, F. Setiawan, R. Prasetia, S. T. Pardede, \& S. Campbell. 2008. Technical Report-Ecological Survey on Coral Reefs of Simeulue and Banyak Islands-Aceh 2007. WCS-Indonesia Marine Program. Bogor. 16 pp.

Hernawan, U. E. 2009. Studi populasi kima (Cardiidae: Tridacninae) di wilayah perairan Kei Kecil, Maluku Tenggara. Laporan Akhir Kegiatan Penelitian UPT Loka Konservasi Biota Laut Tual-Lembaga IImu Pengetahuan Indonesia. Tual. 15 pp.
IUCN. 2007. The IUCN Red List of Threatened Species. (http://www.iucnredlist.org. tanggal akses 18 January 2010).

Kinnaird, M. F. 2002. Sulawesi Utara: Sebuah Panduan Sejarah Alam. Percetakan Redikencana. Jakarta. 82 pp.

Kinch, J. 2002. Giant clams: their status and trade in Milne Bay Province, Papua New Guinea. Traffic Bulletin. 19 (2): 1-9.

Klumpp, D. W. \& C. L. Griffiths. 1994. Contributions of phototrophic and heterotrophic nutrition to the metabolic and growth requirements of four species of giant clams (Tridacnidae). Marine Ecology Progress Series. 115: 103-115.

Knop, D. 1996. Giant Clams, a Comprehensive Guide to the Identification and Care of Tridacnid Clams. Dahne Verlag. Ettlingen. 251 pp.

Lamprell, K. \& T. Whitehead. 1992. Bivalves of Australia Vol. 1. Crawford House Press. New South Wales. 78 pp.

McKenna, S. A., G. R. Allen, \& S. Suryadi (eds.). 2002. A marine rapid assessment of the Raja Ampat Islands, Papua Province, Indonesia. RAP Bulletin of Biological Assessmant 22. Cl. Washington D.C. $191 \mathrm{pp}$.

Mudjiono. 1988. Catatan beberapa aspek kehidupan kima, Suku Tridacnidae (Mollusca, Pelecypoda). Oseana. $12(2)$ : 37-47.

Newman, W. A. \& E. D. Gomez. 2002. On the status of giant clams, relics of tethys (Mollusk: Bivalvia: Tridacnidae). Proceeding of the $9^{\text {th }}$ International Coral Reef Symposium Bali, 23-27 October 2000 II. 927-936.

Panggabean, L. M. G. 1985. Keadaan stok kima (Tridacnidae) di perairan Pulau Pari, Kepulauan Seribu, Teluk Jakarta. Laporan Pusat Penelitian Oseanografi-Lembaga IImu Pengetahuan Indonesia. Jakarta. 120 pp.

Pet-Soede, L. \& M. V. Erdmann (eds.). 2003. Rapid Ecological Assessment Wakatobi National Park. A Joint Publication by WWF-TNC. Jakarta. 187 pp. 
Planes, S., C. Chauvet, J. Baldwin, J. Bonvallot, Y. Fontaine-Vernaudon, C. Gabrie, P. Holthus, C. Payri, \& R. Galzin. 1993. Impact of tourism related fishing on Tridacna maxima (Mollusca: Bivalvia) stocks in Bora-Bora Lagoon (French Polynesia). Attol Research Bulletin 385. National Museum of Natural History, Smithsonian Institution, Washington D. C.

Poorten, J. J. 2007. Results of the rumphius biohistorical expedition to Ambon (1990). Part 13. Mollusca, Bivalvia, Cardiidae. Zool Med. Leiden 81 (15) 8. vi: 259-301.

Snedecor, G. W. \& W. G. Cochran. 1980. Statistical Methods, Seventh Edition. lowa State University Press. Ames. lowa.

Tan, K. S. \& W. W. Kastoro. 2004. A small collection of gastropods and bivalves from the Anambas and Natuna Islands, South China Sea. The Raffles Bulletin of Zoology. 11: 47-54.

Taufik, A. W. 1987. Marine conservation potentials of Aru Island, South-East Maluku. Proceedings of the Symposium on Coral Reef Management in Southeast Asia. SEAMEO-BIOTROP. Bogor. 159167.
Taylor, J. D. 1971. Reef associated molluscan assemblage in the western Indian Ocean. Symposium of the Zoological Society of London. 28: 510-534.

Upanoi, T. \& S. Banchungmanee. 2000. Giant clams in the Andaman Sea, Thailand. Part 2: Distribution and Abundance at Adang, Bitsi, Hin-Ngam, Lipe, and Ta Lang Islands. Phuket Marine Biological Center Special Publication. 21 (1): 75-81.

Usher, G. F. 1984. Coral reef invertebrates in Indonesian their exploitantion and conservation needs. Rep. IUCN/WWF Project 1968 IV. Bogor. $100 \mathrm{pp}$.

Wabnitz, C., M. Taylor, E. Green, \& T. Razak. 2003. From Ocean to Aquarium: The Global Trade in Marine Ornamental Species. UNEP-WCMC. Cambridge, U.K.

Yusuf, C. 2007. Kepadatan kima (famili: Tridacnidae) di perairan Krakatau, Kepulauan Seribu dan Manado. Skripsi. Jurusan IImu Kelautan Universitas Diponegoro. Semarang. 